\title{
Anxiety Level and Risk Factors in Medical Students
}

\author{
Arisyna ${ }^{1}$, Florentina Sustini ${ }^{2}$, Nalini Muhdi ${ }^{3}$
}

${ }^{1}$ Faculty of Medicine, Universitas Airlangga, Surabaya, Indonesia.

2Department of Public Health and Preventive Medicine, Faculty of Medicine, Universitas Airlangga, Surabaya, Indonesia. ${ }^{3}$ Department of Psychiatry, Faculty of Medicine, Universitas Airlangga, Surabaya, Indonesia.

\section{A B S T R A C T}

Introduction: Medical students are more susceptible to anxiety than non-medical students. This study aimed to describe the anxiety level and its risk factors among the first, third, and fifth year medical students in Universitas Airlangga.

Methods: We conducted cross-sectional study involving 195 medical students by consecutive sampling. The inclusion criteria in this study were all first, third, and fifth year medical students who were willing to participate in the study. The data was recorded using questionnaire of anxiety risk factors, Hamilton Rating Scale for Anxiety, and Miller and Smith Stress Vulnerability Scale. All data then was processed and analyzed descriptively.

Results: From 195 students, 57 male $(29.2 \%)$ and 138 female $(70.8 \%)$ students participated, consisted of 63 first year, 68 third year, and 64 fifth year students. Anxiety mostly occurred in fifth year students $(20.3 \%)$, followed by first year students $(19 \%)$, and third year students (11.8\%). Anxiety mostly occured in male (24.6\%), at the age of $17(33.3 \%)$, susceptible to stress $(75 \%)$, dissatisfied with physical condition $(29.2 \%)$, had chronic diseases $(26.4 \%)$, on middle birth order $(34.6 \%)$, had frequent conflict with parents in almost every month (50\%), lived in dorm (20\%), had no close friends $(33.3 \%)$, perceived that health was not important $(100 \%)$, orphaned $(18.8 \%)$, low parental income (35\%), overburdened with examination $(26.3 \%)$, and dissatisfied with the examination criteria (26.5\%).

Conclusion: Fifth year medical students had the highest frequency of anxiety, while third year students had the lowest frequency. Nevertheless, based on the age, anxiety mostly occurred at the age of 17 . These conditions were caused by some risk factors.

(c) 2020 JUXTA: Jurnal Ilmiah Mahasiswa Kedokteran Universitas Airlangga. Available at https://e-journal.unair.ac.id/juxta

\section{*Correspondence: florentina_sustini@yahoo.com}

JUXTA: Jurnal IImiah Mahasiswa Kedokteran Universitas Airlangga

p-ISSN: 1907-3623; e-ISSN: 2684-9453

DOI: 10.20473/juxta.V11I22020.79-82

Open access under Creative Commons Attribution-ShareAlike 4.0 International License

(CC-BY-SA)

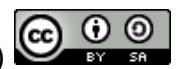

\section{ARTICLE INFO}

\author{
Article history: \\ Received 19 June 2020 \\ Received in revised form 3 July \\ 2020
}

Accepted 20 July 2020

\section{Keywords:}

Anxiety,

Medical student,

HARS,

Miller and Smith Stress

Vulnerability Scale. 


\section{Introduction}

Nowadays, mental health becomes an apprehensive issue, including among the students. Anxiety is the most common mental health problem in students $(41.6 \%)$, followed by depression (36.4\%), and the remaining $35.8 \%$ are interpersonal relationships problems. ${ }^{1}$ Medical students are more susceptible to anxiety than non-medical students, with the highest frequency occur at third and fourth years. ${ }^{2}$ In Asia, a study in Lahore, Pakistan, found that $43.7 \%$ of female students experienced anxiety and $19.5 \%$ experienced depression. The prevalence of anxiety at first, second, third, fourth, and fifth year students was $35.0 \%, 30.0 \%, 20 \%, 55.2 \%$ and $46.7 \%$, respectively. ${ }^{3}$ In Multan, Pakistan, the prevalence of anxiety and depression at first, second, third, fourth, and last year was $45.86 \%$, $52.58 \%, 47.14 \%, 28.75 \%$, and $45.10 \%$ sequentially. ${ }^{4}$ Data in Indonesia, from Faculty of Medicine, Sebelas Maret University, found the anxiety level between the preclinical students and co-assistants was significantly different, where co-assistant students were more anxious and depressive than preclinical students. ${ }^{5}$

A study showed that every individual has basic anxiety that would make a person more likely to experience anxiety in a stressful situation. This basic anxiety was part of the personality formed by life experience. ${ }^{6}$ All of the factors are classified into two, i.e. internal factors (gender, history of chronic ilness, physical condition, perception of health, stress vulnerability, and personality) and external factors (year of study, parental status, domicile, number of close friends, frequency of conflict with parents, economic status, birth order, examination loads, and examination criteria dissatisfaction). This study described both internal and external factors, except personality. There are no studies that describe the level of anxiety, especially in students in Faculty of Medicine, Universitas Airlangga. Therefore, this study aimed to describe the level of anxiety in first, third, and fifth year students in Faculty of Medicine,
Universitas Airlangga, to help identify early and determine the intervention or ways to reduce it. Moreover, it is expected that the study performance and the potential of first, third, and fifth year medical students of Universitas Airlangga can enhace optimally.

\section{Methods}

This study was a descriptive study with cross-sectional design conducted in Faculty of Medicine, Universitas Airlangga from July 2014 to September 2015. The sample of this study was 195 first, third, and fifth year students of Faculty of Medicine, Universitas Airlangga in the year of 2014-2015. The inclusion criteria in this study were all first, third, and fifth year medical students who were willing to participate in the study, while the exclusion crietria were students who had not passed the sub-program yudisium or had taken leave of at least one semester. This study used three questionnaire: Hamilton Rating Scale for Anxiety ${ }^{7}$, Miller and Smith Stress Vulnerability ${ }^{8}$, and a questionnaire listing internal and external risk factors which was validated. All subjects gave written informed consent. The data were collected by fulfilling the questionnaire online and offline, then processed and analyzed descriptively.

\section{Results}

This study conducted in Faculty of Medicine, Universitas Airlangga from July 2014 to September 2015, involving 195 students consisted of 68 third year students, followed by 64 fifth year students, and 63 first year students. The age varied from 17 to 25 years old and was dominated by female students. Table 1 describes the prevalence of anxiety based on the characteritics of the subjects. Although majority of the students had no anxiety, anxiety mostly occurred in the first and the fifth year students with a slight difference.

Table 1. The characteristics of the subjects

\begin{tabular}{|c|c|c|c|c|c|c|}
\hline \multirow[b]{2}{*}{ Variables } & \multirow{2}{*}{$\begin{array}{l}\text { Frequency } \\
\qquad=195\end{array}$} & \multicolumn{5}{|c|}{ Anxiety Level } \\
\hline & & $\begin{array}{c}\text { No anxiety } \\
\mathrm{n}(\%)\end{array}$ & $\begin{array}{l}\text { Mild } \\
\text { n(\%) }\end{array}$ & $\begin{array}{l}\text { Moderate } \\
\mathrm{n}(\%)\end{array}$ & $\begin{array}{c}\text { Severe } \\
\mathrm{n}(\%)\end{array}$ & $\begin{array}{c}\text { Very Severe } \\
\mathrm{n}(\%)\end{array}$ \\
\hline \multicolumn{7}{|l|}{ Year of Study } \\
\hline First & 63 & $51(81)$ & $6(9.5)$ & $4(6.3)$ & $2(3.2)$ & $0(0)$ \\
\hline Third & 68 & $60(88.2)$ & $3(4.4)$ & $2(3)$ & $3(4.4)$ & $0(0)$ \\
\hline Fifth & 64 & $51(79.7)$ & $9(14)$ & $3(4.7)$ & $1(1.6)$ & $0(0)$ \\
\hline \multicolumn{7}{|l|}{ Gender } \\
\hline Male & 57 & 119 (86.2) & $10(7.2)$ & $6(4.4)$ & $3(2.2)$ & $0(0)$ \\
\hline Female & 138 & $43(75.4)$ & $8(14)$ & $3(5.3)$ & $3(5.3)$ & $0(0)$ \\
\hline \multicolumn{7}{|l|}{ Age } \\
\hline 17 & 9 & $6(66.7)$ & $1(11.1)$ & $1(11.1)$ & $1(11.1)$ & $0(0)$ \\
\hline 18 & 19 & $18(94.7)$ & $1(5.3)$ & $0(0)$ & $0(0)$ & $0(0)$ \\
\hline 19 & 33 & 25 (75.9) & $4(12.1)$ & $3(9.1)$ & $1(3)$ & $0(0)$ \\
\hline 20 & 29 & 25 (86.2) & $1(3.4)$ & $1(3.4)$ & $2(7)$ & $0(0)$ \\
\hline 21 & 42 & 37 (88.1) & $3(7.1)$ & $1(2.4)$ & $1(2.4)$ & $0(0)$ \\
\hline 22 & 21 & $18(85.7)$ & $2(9.5)$ & $0(0)$ & $1(4.8)$ & $0(0)$ \\
\hline 23 & 39 & 30 (76.9) & $6(15.4)$ & $3(7.7)$ & $0(0)$ & $0(0)$ \\
\hline 24 & 2 & $2(100)$ & $0(0)$ & $0(0)$ & $0(0)$ & $0(0)$ \\
\hline 25 & 1 & $1(100)$ & $0(0)$ & $0(0)$ & $0(0)$ & $0(0)$ \\
\hline
\end{tabular}


Table 2. Description of anxiety levels based on the year of study, gender, age, physical condition satisfaction, health perception, history of chronic illness, parental status, domicile, number of close friends, birth orders, frequency of conflict with parents, parental income, examination loads, satisfaction towards examination criteria, and levels of stress vulnerability.

\begin{tabular}{|c|c|c|c|c|c|c|}
\hline \multirow{2}{*}{ Variables } & \multirow{2}{*}{$\begin{array}{c}\text { Frequency } \\
\quad N=195\end{array}$} & \multicolumn{5}{|c|}{ Anxiety Level } \\
\hline & & $\begin{array}{c}\text { No anxiety } \\
\mathrm{n}(\%)\end{array}$ & $\begin{array}{l}\text { Mild } \\
\text { n(\%) }\end{array}$ & $\begin{array}{c}\text { Moderate } \\
\mathrm{n}(\%)\end{array}$ & $\begin{array}{c}\text { Severe } \\
\mathbf{n}(\%)\end{array}$ & $\begin{array}{c}\text { Very Severe } \\
\mathrm{n}(\%)\end{array}$ \\
\hline \multicolumn{7}{|l|}{$\begin{array}{l}\text { Physical } \\
\text { Satisfaction }\end{array}$} \\
\hline Yes & 147 & $128(87.1)$ & $13(8.8)$ & $4(2.7)$ & $2(1.4)$ & $0(0)$ \\
\hline No & 48 & $34(70.8)$ & $5(10.4)$ & $5(10.4)$ & $4(8.4)$ & $0(0)$ \\
\hline \multicolumn{7}{|l|}{$\begin{array}{l}\text { Health } \\
\text { Perception }\end{array}$} \\
\hline Important & 194 & $162(83.5)$ & $17(8.8)$ & $9(4.6)$ & $6(3.1)$ & $0(0)$ \\
\hline Unimportant & 1 & $0(0)$ & $1(100)$ & $0(0)$ & $0(0)$ & $0(0)$ \\
\hline \multicolumn{7}{|l|}{$\begin{array}{l}\text { History of } \\
\text { Chronic Illness }\end{array}$} \\
\hline No & 176 & $148(84.1)$ & $15(8.5)$ & $8(4.5)$ & $5(2.9)$ & $0(0)$ \\
\hline Yes & 19 & $14(73.6)$ & $3(15.8)$ & $1(5.3)$ & $1(5.3)$ & $0(0)$ \\
\hline \multicolumn{7}{|l|}{ Parental Status } \\
\hline $\begin{array}{l}\text { Both live and } \\
\text { together } \\
\text { One or both }\end{array}$ & 171 & $142(83)$ & $15(8.8)$ & $9(5.3)$ & $5(2.9)$ & $0(0)$ \\
\hline has died & 16 & $13(81.2)$ & $3(18.8)$ & $0(0)$ & $0(0)$ & $0(0)$ \\
\hline $\begin{array}{l}\text { Both live but } \\
\text { divorced }\end{array}$ & 8 & $7(87.5)$ & $0(0)$ & $0(0)$ & $1(12.5)$ & $0(0)$ \\
\hline \multicolumn{7}{|l|}{ Domicile } \\
\hline Home & 110 & $94(85.5)$ & $10(9.1)$ & $3(2.7)$ & $3(2.7)$ & $0(0)$ \\
\hline Dorm & 85 & $68(80)$ & $8(9.4)$ & $6(7)^{\prime}$ & $3(3.6)$ & $0(0)$ \\
\hline \multicolumn{7}{|l|}{$\begin{array}{l}\text { Number of } \\
\text { Close Friends }\end{array}$} \\
\hline$>5$ & 139 & $120(86.3)$ & $10(7.2)$ & $6(4.3)$ & $3(2.2)$ & $0(0)$ \\
\hline $3-5$ & 35 & $27(77.2)$ & $4(11.4)$ & $2(5.7)$ & $2(5.7)$ & $0(0)$ \\
\hline $1-2$ & 18 & $13(72.1)$ & $3(16.7)$ & $1(5.6)$ & $1(5.6)$ & $0(0)$ \\
\hline 0 & 3 & $2(66.7)$ & 1 (33.3) & $0(0)$ & $0(0)$ & $0 \quad(0)$ \\
\hline \multicolumn{7}{|l|}{ Birth Order in } \\
\hline $\begin{array}{l}\text { Siblings } \\
\text { The last }\end{array}$ & 67 & $57(85.1)$ & $5(7.5)$ & $3(4.5)$ & $2(2.9)$ & $0(0)$ \\
\hline Middle & 26 & $17(65.4)$ & $2(7.7)$ & 5 (19.2) & $2(7.7)$ & $0(0)$ \\
\hline The first & 102 & $88(86.3)$ & $11(10.8)$ & $1(1)$ & $2(1.9)$ & $0(0)$ \\
\hline \multicolumn{7}{|l|}{$\begin{array}{l}\text { Conflict with } \\
\text { Parents }\end{array}$} \\
\hline Rarely & 154 & $136(88.3)$ & $12(7.8)$ & $6(3.9)$ & $0(0)$ & $0(0)$ \\
\hline $\begin{array}{l}\text { Almost every } \\
\text { month }\end{array}$ & 23 & $17(73.9)$ & $2(8.7)$ & $2(8.7)$ & $2(8.7)$ & $0(0)$ \\
\hline $\begin{array}{l}\text { Almost every } \\
\text { week }\end{array}$ & 18 & $9(50)$ & $4(22.2)$ & $1(5.6)$ & $4(22.2)$ & $0(0)$ \\
\hline \multicolumn{7}{|l|}{ Parental Income } \\
\hline $\begin{array}{l}\text { Wage } \\
<\text { Minimum }\end{array}$ & 175 & $149(85.1)$ & $14(8)$ & $9(5.1)$ & $3(1.8)$ & $0(0)$ \\
\hline Wage & 20 & $13(65)$ & $4(20)$ & $0(0)$ & $3(15)$ & $0(0)$ \\
\hline \multicolumn{7}{|l|}{ Examination } \\
\hline $\begin{array}{l}\text { Loads } \\
\text { Light }\end{array}$ & 23 & $21(91.4)$ & $1(4.3)$ & $1(4.3)$ & $0(0)$ & $0(0)$ \\
\hline Moderate & 134 & $113(84.3)$ & $15(11.1)$ & $4(2.1)$ & $2(1.5)$ & $0(0)$ \\
\hline Heavy & 38 & $28(73.7)$ & $2(5.3)$ & $4(10.5)$ & $4(10.5)$ & $0(0)$ \\
\hline \multicolumn{7}{|l|}{$\begin{array}{l}\text { Examination } \\
\text { Criteria } \\
\text { Satisfaction }\end{array}$} \\
\hline Yes & 112 & $101(90.2)$ & $10(8.9)$ & $1(0.9)$ & $0(0)$ & $0(0)$ \\
\hline No & 83 & $61(73.5)$ & $8(9.6)$ & $8(9.6)$ & $6(7.3)$ & $0(0)$ \\
\hline \multicolumn{7}{|l|}{$\begin{array}{l}\text { Levels of } \\
\text { Stress }\end{array}$} \\
\hline $\begin{array}{l}\text { Vulnerability } \\
\text { Good }\end{array}$ & 94 & $88(93.6)$ & $3(3.2)$ & $2(2.2)$ & $1(1)$ & $0(0)$ \\
\hline Moderate & 93 & $72(77.4)$ & $11(11.8)$ & $6(6.5)$ & $4(4.3)$ & $0(0)$ \\
\hline Poor & 8 & $2(25)$ & $4(50)$ & $1(12.5)$ & $1(12.5)$ & $0(0)$ \\
\hline
\end{tabular}


Table 2. shows that anxiety was influenced by some risk factors. Those who were satisfied with their body condition, had good health perception, had no history of chronic illnesses, had good social support including friends and family were less likely to have anxiety. Moreover, those who did not feel overburdened with their academic load, and had good stress immunity were easier to avoid anxiety.

\section{Discussion}

From this study, we found that anxiety was common in medical students and influenced by many factors. The previous study showed that anxiety mostly occurred in the first, third, and fifth year students, with a percentage of $45.86 \%, 47.14 \%$, and $45.10 \%$ sequentially. ${ }^{4}$ It is in contrast with this study, where the highest prevalence of anxiety was in fifth year students. A study in Faculty of Medicine, Sebelas Maret University showed that co-assistant students were more anxious and depressive. ${ }^{5}$ In this study, anxiety mostly occurred in the first and the fifth year students, with a slight difference higher in the fifth year students.

Anxiety is known to be related to parental status, domiciles, and the number of close friends. The majority of anxiety occured in students who were orphan, lived in dormitories, and had few close friends. ${ }^{3}$ Based on age, the older the students, the frequency of anxiety will also increase. Nevertheless, in this study, the highest prevalence of anxiety was at the age of 17 years old, which was because there was cognitive maturity where there is a transition between concrete operational thinking towards a more abstract mindset. ${ }^{9}$ The previous study also reported that anxiety was related to gender, birth order, examination loads, and dissatisfaction with the test criteria. ${ }^{10}$ The highest prevalence of anxiety was found in female and the youngest children. This study had the same results, except for gender and birth order. In this study, the highest prevalence of anxiety was in male and middle births. This condition can be caused by the sense of responsibility and life demands in male is relatively heavier than female. While the middle births students experienced more anxiety because the demands of oneself and the family that being an older sibling means giving a good example, such as being successful in the academic field. ${ }^{11} \mathrm{~A}$ study stated that anxiety was related to satisfaction with the condition of the body, health perception, history of having chronic disease, conflict with parents, and economic status. ${ }^{11}$ This study had the same results where the highest prevalence of anxiety was found in students who were not satisfied with their body condition, perceived that health was not important, had history of chronic diseases, had conflict with parents frequently, and parental income under minimum wage. Whereas based on stress vulnerability, the result of this study was similar to the previous study where the students whose stress vulnerability was good, the less likely the prevalence of anxiety would come. ${ }^{12}$
This study has some limitations; firstly, there was no data on anxiety in general population. Secondly, the questionnaire depended upon self-reported measures. Thirdly, the students tended to finish their questionnaire in a short time because of limited time. Fourthly, the anonymity of this study made it impossible to recheck the results.

\section{Conclusion}

We concluded that anxiety in medical students mostly occurred in the first and the fifth year students with a slight difference. There is a need for the counseling services to decrease the morbidity caused by anxiety.

\section{CONFLICT OF INTEREST}

The author stated there is no conflict of interest in this study.

\section{REFERENCES}

1. Association AP. College Students' Mental Health is a Growing Concern, Survey Finds. In: Psychology Mo, (ed.). Washington DC2013.

2. Rosenthal JM and Okie S. White Coat, Mood Indigo Depression in Medical School The New England Journal of Medicine. 2005.

3. Rab F, Mamdou R and Nasir S. Rates of Depression and Anxiety among Female Medical Students in Pakistan. Eastern Mediterranean Health Journal 2008; 14: 126-33.

4. Jadoon N, Yaqoob R, Raza A, Shehzad M and Zeshan S. Anxiety and Depression among Medical Students: A cross-Sectional Study. Journal of Pakistan Medical Association. 2010; 60: 699-702.

5. Widosari Y. Perbedaan Derajat Kecemasan dan Depresi Mahasiswa Kedokteran Preklinik dan Ko-asisten di FK UNS Surakarta Surakarta: Universitas Sebelas Maret, 2010

6. Auliani R. Hubungan Antara Tipe Kecemasan dengan Prestasi Belajar Statistik Mahasiswa Fakultas Psikologi UIN Jakarta Jakarta: UIN, 2010.

7. Hamilton M. Hamilton Anxiety rating Scale (HAM-A). 1959

8. Anon. How Vulnerable Are You To Stress? The MillerSmith Lifestyle Assessment Inventory.

9. Sadock B and Sadock V. Kaplan \& Sadock's Synopsis of Psychiatry: Behavioral Sciences/Clinical Psychiatry. Philadelpia: Lippincott Williams \& Wilkins, 2014

10. Alvi T, Assad F, Ramzan M and Khan FA. Depression, Anxiety and Their Associated Factors among Medical Students. Journal of the College of Physicians and Surgeons--Pakistan : JCPSP. 2010; 20: 122-6.

11. Nguyen HT, Dunne MP and Le AV. Multiple Types of Child Maltreatment and Adolescent Mental Health in Viet Nam. 2009.

12. Fitasari I. Faktor yang Berhubungan dengan Kejadian Stress pada Mahasiswa Fakultas Kesehatan Masyarakat Universitas Airlangga Surabaya: Universitas Airlangga, 2011. 